Volume 5, Issue 1,February 2020, pp. 26-37

DOI: $10.23917 /$ jramathedu.v5i1.8741

p-ISSN: 2503-3697, e-ISSN:2541-2590

\title{
Developing complex analysis textbook to enhance students' critical thinking
}

\author{
Fariz Setyawan*, Puguh Wahyu Prasetyo, Burhanudin Arif Nurnugroho \\ Department of Mathematics Education, Universitas Ahmad Dahlan, Indonesia \\ *Corresponding author: fariz.setyawan@pmat.uad.ac.id
}

\begin{tabular}{l} 
ARTICLE INFO \\
\hline Article history: \\
Received: 30 August 2019 \\
Revised: 4 January 2020 \\
Accepted: 7 January 2020 \\
Published online: 28 February \\
2020 \\
Published regularly: February \\
2020
\end{tabular}

Keywords:

Critical thinking, textbook, complex numbers

\section{ABSTRACT}

Critical thinking skill was needed since problems in daily life required a solution. To solve the problems, the students collect the data as a consideration in making the right decision. Moreover, the students also need good critical thinking skills. To develop a good critical thinking skill, the researcher develops a textbook of Complex Analysis and Application, especially in complex numbers. In this research, a qualitative investigation was carried out in the development of the textbook. This textbook supports the mathematics education students of Universitas Ahmad Dahlan in learning complex analysis course. Researchers did a walkthrough to the expert in assessing the content and construct to validate the textbook. The development model used by researchers is a 4D model. A 4-D model used in this study is consists of defining, designing, developing, and disseminating. In defining, the researcher adequate materials related to the complex numbers such as the rational number and real number and its properties in addition and multiplication. In designing, some explanation in the textbook is followed by Why and How questions. Open questions are used to stimulate the students' critical thinking. Based on the walkthrough result, some notation in the textbook, especially mathematics symbols, must be revised using a proper mathematics equation. In addition, some concept should be clearly defined such as $\mathrm{z}^{-1}=\frac{1}{\mathrm{z}}$ where the value of $\mathrm{z} \neq 0$. As a result of the validity construct, the explanation given in the textbook used a step-bystep exercise. In disseminating, the students can easily access the textbook and answer the questions using their reasoning. The textbook is valid and readable.

(C) 2020 Universitas Muhammadiyah Surakarta

\section{Introduction}

HOTS-based learning is often associated with the ability to solve mathematical problems (Rahayunigrum, Setyawan, \& Khasanah, 2018). In problem-solving activities, students are required to understand the problems, develop strategies, implement strategies, and evaluate the results. The process is one of the lecturer's priorities as a facilitator in the classroom in delivering the teaching material to the students. They are expected to be able to understand, to associate, and to apply mathematical concepts accurately, precisely, and efficiently in determining the right strategy while solving a problem. Krulik and Rudnick state that high-level thinking skills (HOTS) include basic 
thinking, creative thinking, and critical thinking (Krulik \& Rudnick, 1995). Critical thinking is one of the $21^{\text {st }}$-century skills needed nowadays. Eight descriptions can be associated with critical thinking. There are testing, connecting, and evaluating all aspects of the problem, focusing on the part of the problem, gathering and organizing information, validating, remembering, determining the answer, drawing valid conclusions, and conducting analytical and reflexive thinking. Critical thinking can be associated while the students solve the problem given by the teaching and learning process.

College students, in undergraduate programs, should improve their critical thinking skills since the lecturer may concern students' memorization in the learning process (Schmidt, Wagener, Smeets, Keemink, \& van der Molen, 2015). In the conventional teaching method, the lecturer is often assuming that students can develop their critical thinking naturally from the complex levels or some discipline content. However, students do not always control what they have done (Cahdriyana, Richardo, Fahmi, \& Setyawan, 2019). Both lecturers and students should understand that mathematics is about the idea (Himmah, Nayazik, \& Setyawan, 2019). Students' understanding can be constructed by solving the problems (Panasuk, 2010). This activity involves students' ability to think critically. The lecturer, as the facilitator, develops students' critical thinking by constructing students' ideas explicitly and consciously. It is beginning with simple operations and building toward the complexity. Students should memorize and understand the concept from its terms, issues, methodologies. They are learning the concept by recalling their experiences and previous learning through application, analysis, evaluation, and creation (Setyawan, 2015). Some skill associated with the concept of critical thinking is understanding problems, classifying information to solve problems, understanding the assumptions, formulating and deriving relevant hypotheses, drawing valid conclusions and determining the validity of the conclusions (Helmstadter, 1965). Ennis said that there are six components in critical thinking skills such as focus, reason, inference, situation, clarity, and overview (Ennis, 1958).

First, the focus is related to the identification of the problem. This problem should be included in the conclusion of an argument. Next, the reason must be accepted logically or not. The reason, which is accepted logically, can support the conclusion, namely inference. After that, the students should make a correction based on the situation given. In this step, they clarify the term is used. Last, they do an overview of all results as an argument in conclusion. Watson and Glaser made measurements through tests that included five indicators, namely recognizing assumptions, making inferences, deductions, interpretations, and evaluating arguments (Helmstadter, 1965). From the various abilities related to critical thinking presented by experts, it turns out that the measurement of critical thinking skills has been included in the five indicators, as stated by Watson and Glaser. Critical thinking is generally regarded as the main goal of learning. Besides that, critical thinking plays an important role in many types of work, especially jobs that require accuracy and analytical thinking (Helmstadter, 1965). This opinion is also in line with the purpose of mathematics learning, namely that students can use mathematics as a way of reasoning (logical thinking, critical, systematic, and objective) that can be used to solve problems, both in daily life and in learning various sciences. Critical thinking is needed in daily life because human society is always faced with problems that require a solution. To solve a problem, data is needed so that a logical decision can be made. Besides, to make the right decision, the students must have good critical thinking skills. While students develop critical thinking skills, they are actively involved in the learning process. The various elements of learning, such as self-learning, collective learning, passive learning, and active learning, have their place as a part of a series in reinforcing them to develop their critical 
thinking (Zapalska, Nowduri, Imbriale, \& Wroblewski, 2018). The development of a student's critical thinking should be given repeatedly by using learning media while they are studying about one material.

One material studied in mathematics education is the Complex Variables and Application course (FPK). FPK is chosen because its material could be developed for students to learn critically about the concepts given during the learning process. Besides, there is no FPK textbook used by the students during the lecture. The developed learning media is expected to be based on the problem which used High-Order Thinking Skills (HOTS). The learning media's content adapts the needs of students of the Mathematics Education Department. Therefore, researchers are interested in developing HOTS-based FPK learning media. Required through the development of learning tools with HOTS, the students can think critically offered through problems given by lecturers, develop strategies for problem-solving, and are actively involved in learning.

The model used in developing learning media is a 4-D model proposed by Thiagarajan and Semmel, consisting of four stages (Lawhon, 1976). The stages are defining, making a design, developing, and disseminating. However, in this study, dissemination was carried out in small scopes because this study focused on making media for the students who take the FPK course in the mathematics education department of Universitas Ahmad Dahlan. To develop a better understanding of the impact that textbooks, a qualitative investigation was carried out in the development of the Complex Variables and its Application textbook. This final textbook only supports experiments to assess the validity and readability for the mathematics education students in Universitas Ahmad Dahlan. The researchers investigated the FPK textbook that is relevant to improve students understanding of the complex numbers and to stimulate their critical thinking by giving why and how questions.

\section{Research Methods}

This research is descriptive qualitative research with a 4-D development model. The media is a Complex Analysis and its Application (FPK) textbook. The chapter which is discussed is Complex Numbers. The subject of the study is mathematics education department students of Universitas Ahmad Dahlan. The data was taken in August 2019. The 4-D development model used in this study consists of defining, designing, developing, and disseminating. In the defining stages, the researchers are deriving the list of the prerequisite and material of Complex Numbers. In the designing stages, the researcher made a textbook which facilitates students' critical thinking by giving why and how to question in each explanation given in the book. As the developing stages, the textbook is discussed with the expert. This stage aims to get feedback about the material and the concept given in each subchapter. Critics and comments given by the expert are discussed by doing an interview.

The validation of the textbook is using method triangulation. The data is collected using a written test and interview method. The researchers analyze the written comments from the expert. At other times, researchers interview with the same expert as its validation. Since the variable tested by the textbook is the students' critical thinking, the researchers collected all of the expert's feedback from the question given in the textbook. Last, in the disseminating stages, the researchers give the textbook to one class of mathematics education students in Universitas Ahmad Dahlan. Then, the students give feedback about the readable of the textbook. 


\section{Results and Discussion}

The result of the study shows that students not only use the Complex Analysis textbook but also guided by the lecturer. Meanwhile, they use the textbook directly. The following analysis focuses on the utilization of the textbook that students perform in addition to lecturer mediated textbook use.

\section{Defining stage}

In the first step of defining the model, researchers analyze the curriculum of mathematics education department, especially in the complex numbers. In the concept of the complex numbers, the students were able to understand the definition, the notation, the properties, the algebraic operation, the power and root, the interpretation of complex numbers, and the open-ended problem related to the complex number. The prerequisite of the complex numbers is identified as a real number and its properties, rational number, and set of pair-ordered numbers.

\section{Designing stage}

The list is discussed with the expert then revised such that the prerequisite is not only about the subchapter related to the book, but also the course used to be the prerequisite of A complex Analysis, for example, Calculus and Linear Algebra. In this case, the prerequisite of the complex numbers is a rational number and algebraic properties in a real number. the researchers give a comparison between the list of the prerequisite material needed and the list of material which is given. The material is shown in Table 1.

Table 1

Material Analysis

\begin{tabular}{ll}
\hline Pre-requisite & Material \\
\hline Rational Number & Definition of the complex number \\
Real Number & Notation of the complex number \\
Algebraic Operation & The properties of the complex number \\
Trigonometry & Algebraic properties of the complex number \\
Cartesian & The interpretation of the complex number \\
Pole coordinate & Power and root of the complex number \\
\hline
\end{tabular}

After identifying the prerequisite, the researcher started to write the subchapter and formulating the problem related to the material. In the first subchapter, there is an introduction to the complex numbers. After that, the textbook gives three competencies as the objective of learning. First, to understand the definition of the complex number, this subchapter discussed the prerequisite, such as the rational number and real number, the definition in the complex number, and the notation of the complex number. There is an example to make a conceptual understanding of the students about the material (Setyawan, $\underline{2015})$.

\section{Developing stages}

In the subchapter of algebraic operation of the complex number, the students are forced to make an example of one problem which is related to the properties. Solving tasks and problems is associated with activities when students utilized their textbook to get assistance with solving tasks and problems. While students are forced to make an example of the algebraic properties in the complex number, it was also observed that students 
search an adequate heading in the book. They read the textbook from the heading until they find useful information. Based on this activity, it was inferred that these students expect useful information related to a subject at the beginning of a lesson in the textbook (Rezat, 2010). It was relevant to Carey's statement. She said that the development of learning systems is a process of determining and creating certain situations and conditions that cause students to interact so that changes occur in their behavior (Carey, 2011). In this study, the learning device developed is a learning media, a textbook that uses HOTS with good criteria. Its valid content indicates a good textbook. The contents reviewed by the expert can be seen in Figure 1.

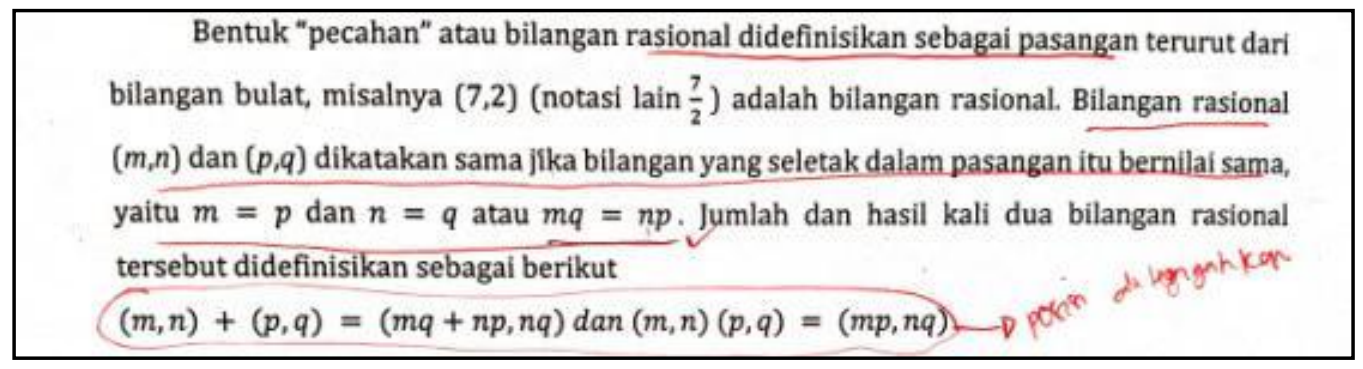

Figure 1. Validation in subchapter Introduction

The definition of a rational number is written in the ordered pair $(m, n)$ and $(p, q)(s e e$ in Figure 1). The expert was interviewed about the notation of rational numbers using ordered pairs. The expert then asked why the statement was underlined. After the discussion, the statement $m=p$ and $n=q$ should be followed by the statement of "or $m q=n p$," and the value of $p$ and $q$ is not equal to zero. The statement should be added a question that forces the students to think critically, for example," what will happen if the statement is not followed by mq-np? Or "what the meaning $\mathrm{mq}=\mathrm{np}$ ?". The next statement should be aligned in the center of the document. The expert feedback is shown in Figure 2.

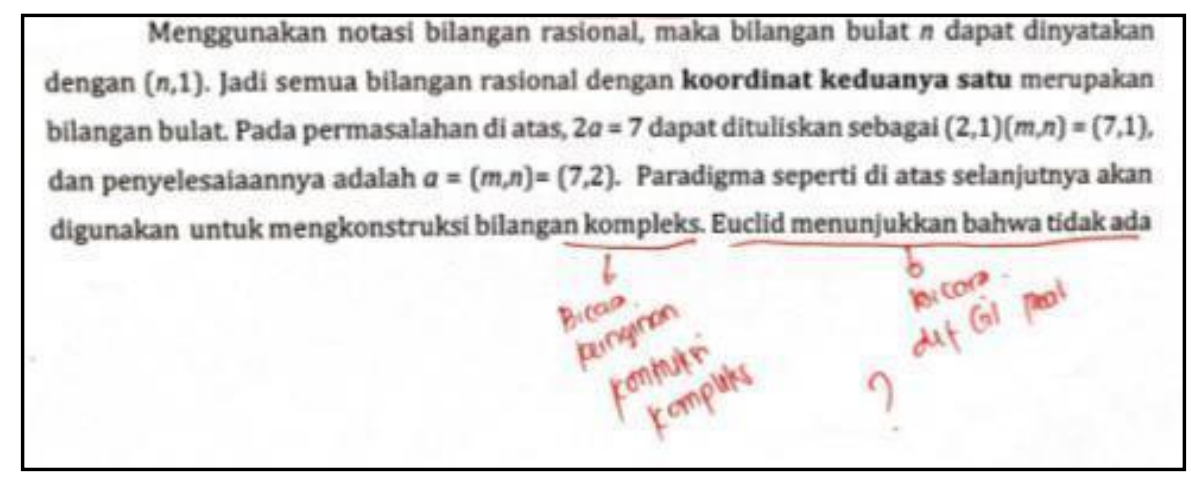

Figure 2. Expert comment in subchapter Introduction

The next review is the construction used in the introduction. The statement said that a rational number is one of the examples used to construct the conceptual understanding of the complex number, but the next statement said about the real number. After interviewed, it was concluded that the textbook needs to explore more about the construction of the imaginary number. It is shown that the subchapter should be revised. Besides, it can start from a natural number to a real number then followed by an imaginary number. The statement can be seen in Figure 3. 


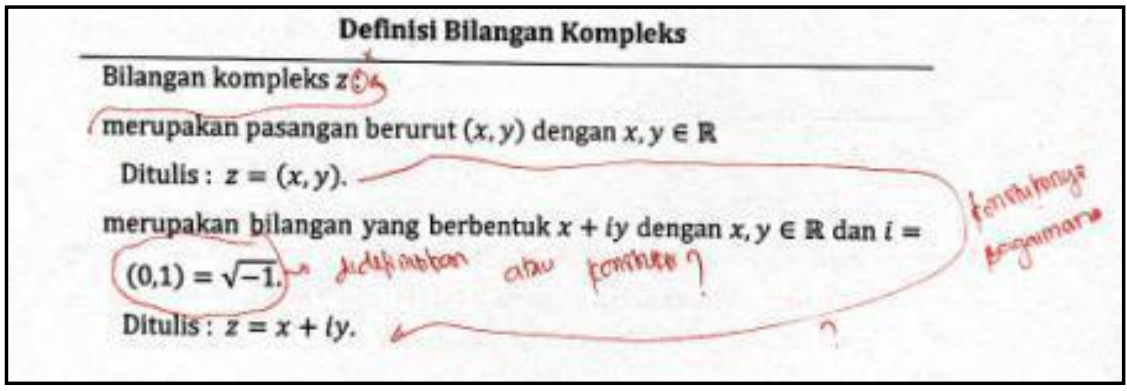

Figure 3. Critical question added in notating the complex number

The notation of the complex number should be questioned since the objective of the learning is improving students' critical thinking. The addition operation should be added by the question about the process of how to get it. The students should answer the question about the effect of this addition (see in Figure 4). As the definition of the complex number can be notated as $\mathrm{z}$, then the notation should be revised as the comment in Figure 4.

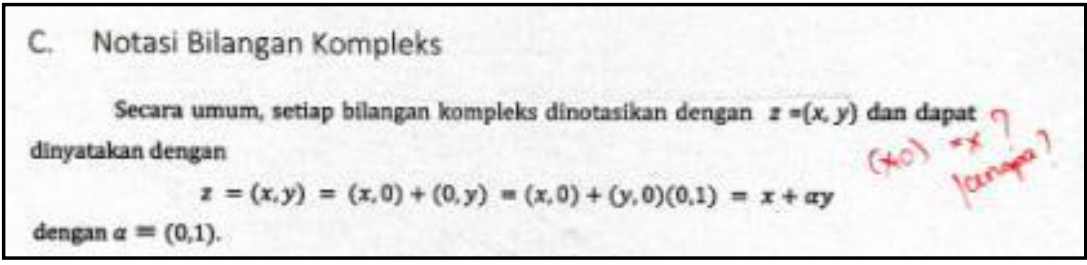

Figure 4. Critical question added in notating the complex number

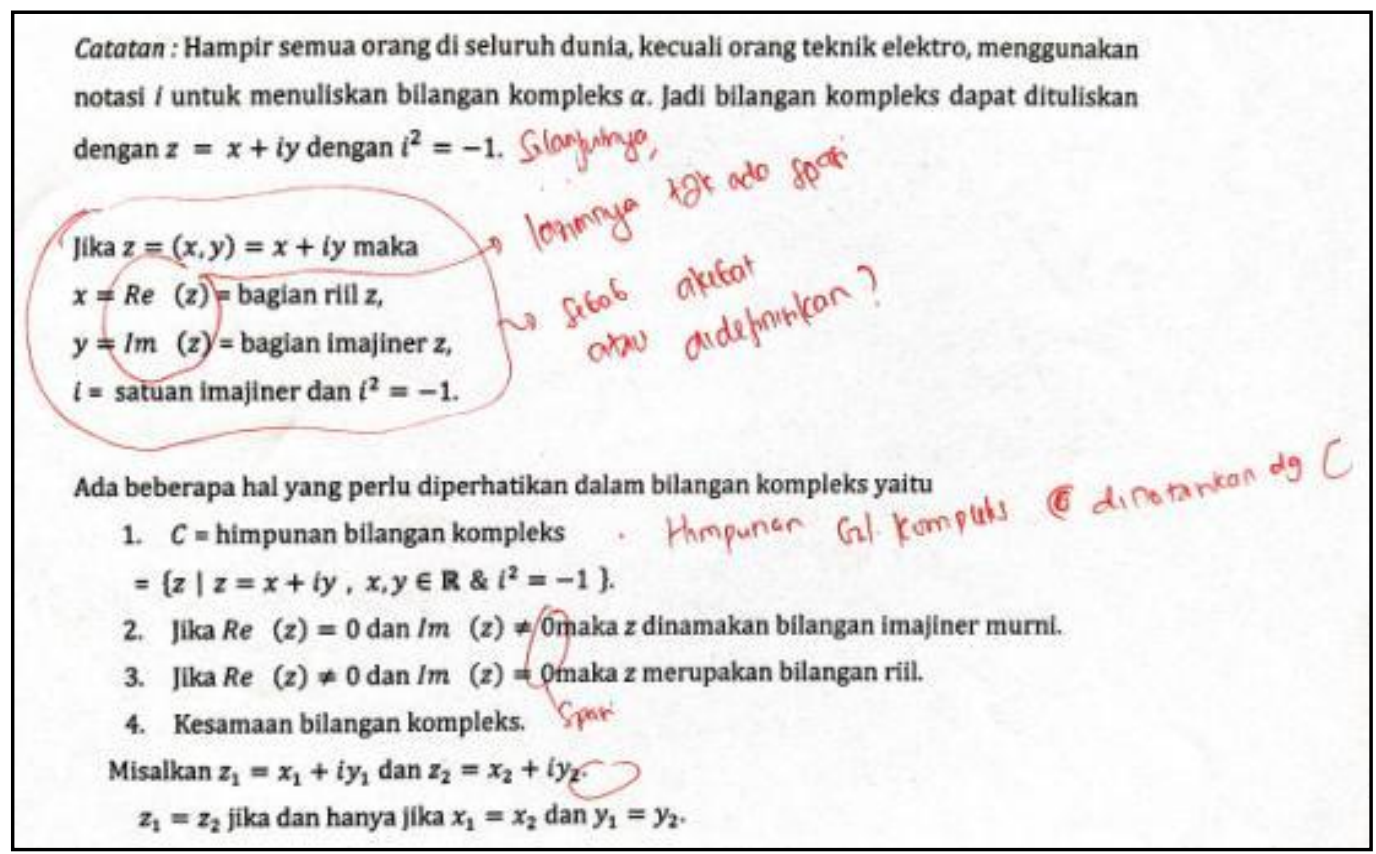

Figure 5. Expert comment in subchapter notation of the complex number

The construction of the imaginary number should be written as the procedure on how to notate it (see in Figure 4). It stimulates the critical thinking of the students to solve. It was relevant to the statement that Critical thinking is generally regarded as the main goal of learning. Besides that, critical thinking plays an important role in many types of work, especially jobs that require accuracy and analytical thinking (Helmstadter, 1965). Unfortunately, for the next subchapter is written the notation of the complex number. 
Thus, the notation of the real numbers should be written as $\operatorname{Re}(z)$. In addition, the notation is followed by the description, as can be seen in Figure 5 .

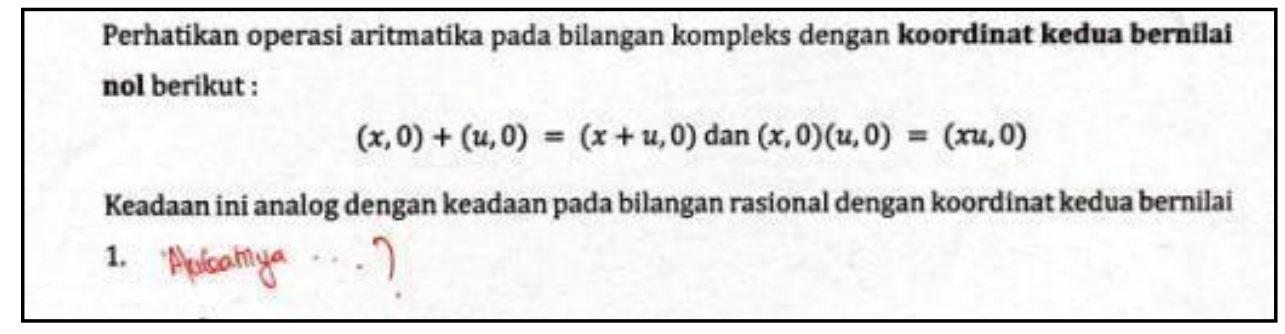

Figure 6. Expert correction about the notation of the complex number

In Figure 6, it is shown that the notation should be revised. Real and Imaginary numbers should be written using mathematics equations and without space. The notation must be cleared to be defined or as the corollary from the definition. The notation can be seen in Figure 7.

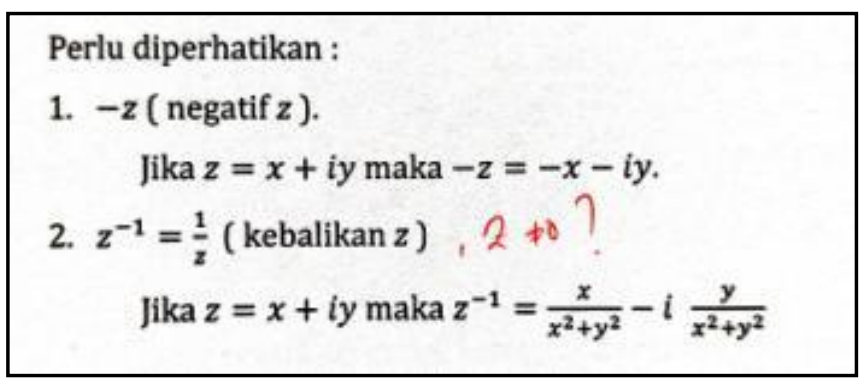

Figure 7. The denominator should be non-zero

In the Algebraic Operation of the complex Number subchapter, the meaning of inverse $\mathrm{z}$ should have a condition that $\mathrm{z}$ is not equal to zero. The notation $\mathrm{z} \neq 0$ can be the discussion to stimulate students' thinks critically (see in Figure 7). It was the same with the notation given in the properties of modulus and conjugate of the complex numbers, as shown in Figure 8.

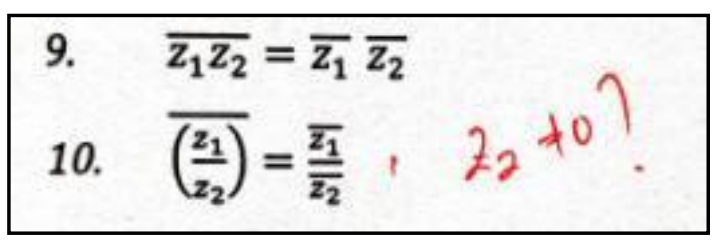

Figure 8. Critical question added in notating the inverse of the complex numbers

In the notation of number 10 of the properties in the complex number, the value of $z_{2} \neq 0$. Since $z_{2}$ is the denominator of the properties, and the conjugate will apply to all numerator and denominator of the term. Besides, the pole coordinate of complex numbers can be seen in Figure 9. As shown in Figure 9, the representation of the complex number in pole coordinate should be given the prerequisite of the expression. This question can be asked to the students to impulse critical thinking. Any critical thinking assignment must be designed on a step-based critical thinking process. 


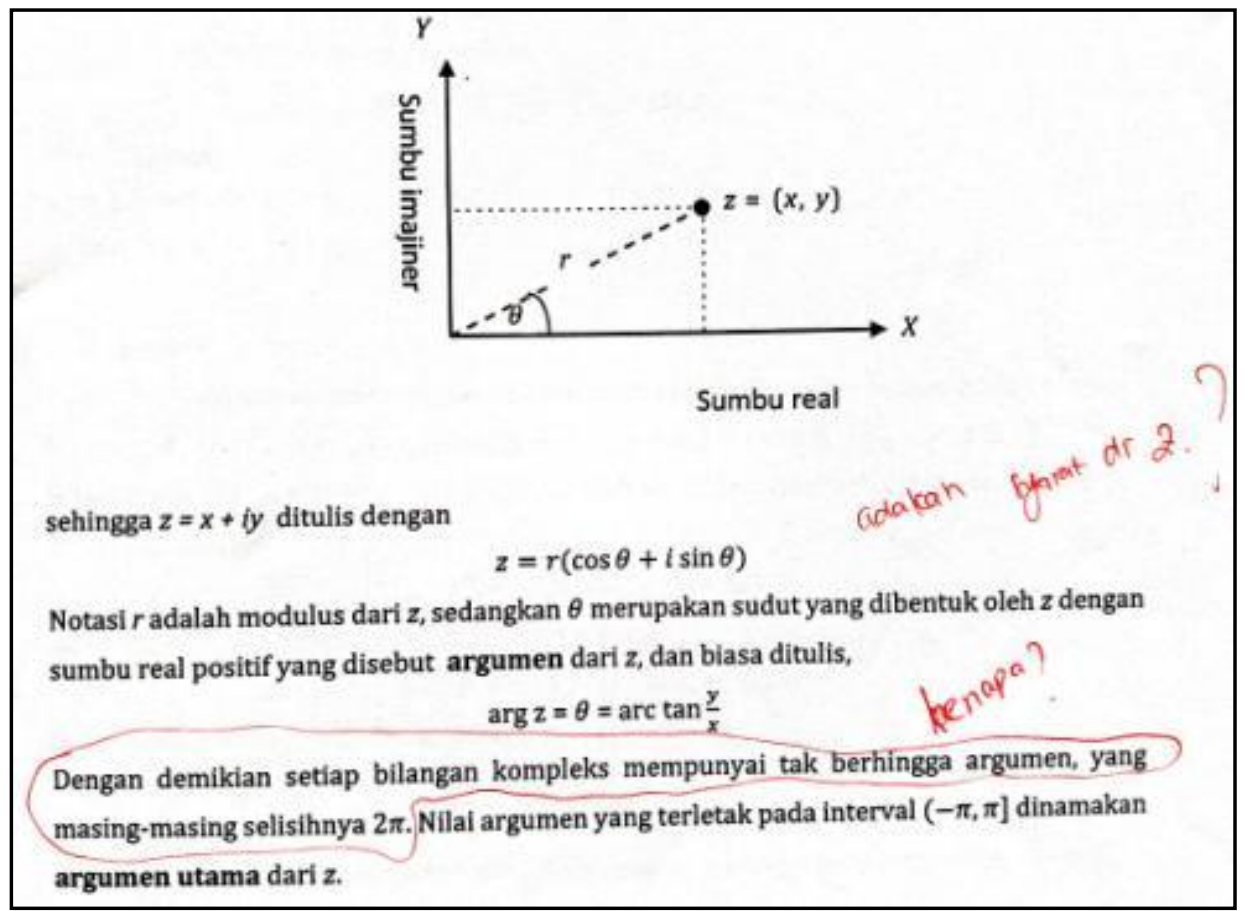

Figure 9. Pole coordinate of the Complex Numbers

\section{Disseminating stages}

To think critically, students need to improve their skills by actively and sequentially practicing the components related to the complex number by critical thinking questions. A conceptual framework of critical thinking can be adopted from the 21st Century Bloom's taxonomy of higher-order thinking skills (Krathwohl, 2002; Himmah et al., 2019). It can serve as a starting point for the development of teaching approaches that foster critical thinking and reasoning (Zapalska et al., 2018; Apriliana, Handayani, \& Awalludin, 2019).

\section{Students' critical thinking}

Stage one, in remembering stages, requires students to remember ideas, words, methods, terminology, and concepts of complex numbers so they can make a connection with the material in Calculus and Algebra, such as the properties of real and rational numbers or the Algebraic operation in real number. At this stage, students will be asked to recognize, list, describe, name, locate, identify, and looking for the information and concepts that they expect to learn.

In the second stage, students are required to understand the statements and information provided. In the understanding stage, the students make the example of a complex number and its properties. They can distinguish the real term $\operatorname{Re}(z)$ and the imaginary terms $\operatorname{Im}(\mathrm{z})$. They were rewriting the definition with their ideas and complementing with notes obtained from supplemental readings so that the meaning of statements and ideas is grasped completely. Students will be expected to interpret, summarize, infer, paraphrase, classify, explain, and compare the concepts they learned. They should begin with simple operations such as recognizing basic issues, identifying or recalling key concepts, learning to ask appropriate questions, and summarizing what they learned.

Next, students can build toward more complex and sophisticated skills, such as making assumptions by answering the question "why the value of $(x, 0)$ is equal $x$ in 
Complex number and creating and critiquing arguments by answering the question "how". To think critically, students should develop their skills continuously and at increasingly by comparing the evidence, evaluating their argument, and making sensible decisions (Changwong, Sukkamart, \& Sisan, 2018; Uribe-Enciso, Enciso, \& Daza, 2017)

In the next four stages, students must translate, recognize the terms, identify, analyze, and apply the concepts learned to the latest learned problems and situations. In this stage, they make inferences and extensions of thinking based on the principles given (Smith, 1977). Particularly, in the applying stage, students require their understanding of the previous concepts to execute specific tasks such as solving the problem, interpreting the concept, or understanding of a new concept. For example, the students use the properties of the complex number and use their properties in solving the problem. In stage four, analyzing stage, students practice in organizing, constructing, comparing, outlining the finding, structuring, and integrating specific concepts into their assignments, projects, or term papers (Zapalska et al., 2018).

In the last stage, students must not only organize and outline concepts and theories, but also, they evaluate the statements which are conveyed by critiquing, checking, experimenting, judging, testing, detecting, and monitoring. Students must make judgments about the material and articulate the reasons for evaluation by answering the question of why in the textbook. At that stage, students must use higher-order thinking such as logical argument, scientific research, empirical evidence rather than lower-order thinking such as peer pressure, confirmation of one's own beliefs in supporting their solution. Besides, they must evaluate the evidence and refines the generalization using appropriate qualifications and the reliability of observation statements. They must also make judgments about their answer and methods. The students make an evaluation when they are considering their answers and method in solving the problem. In that last stage, Creating a creative statement is made. Besides, a logical empirical proposition is developed, which must be sustainable. In this process, students synthesize the material in making, constructing, producing, devising, or inventing something new. The Inquiry cycle of the students while using the textbook can be seen in Figure 10.

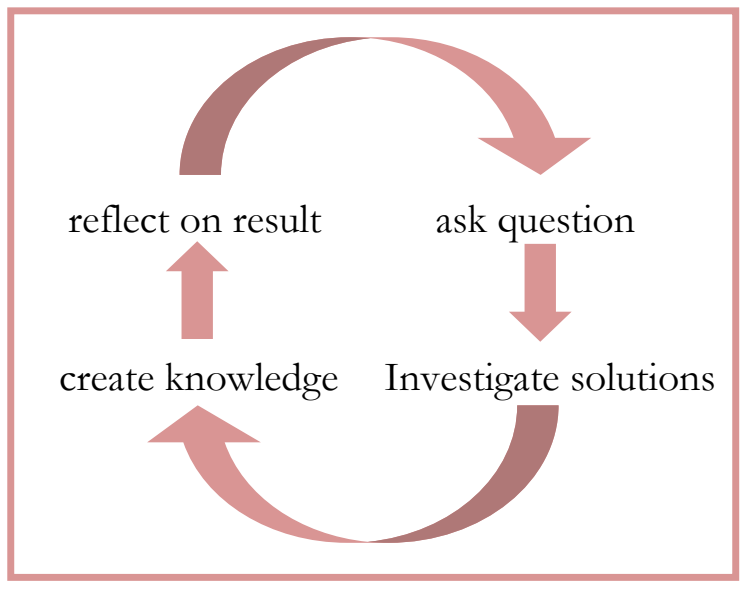

Figure 10. Inquiry Cycle

In the development of the textbook, critical thinking is used in the formal evaluation or construction of the statement given. It is relevant to the study derived by Khabibah. It said that by knowing what constitutes an argument will help you identify what is happening when someone makes an inadequate solution (Khabibah, Manuharawati, \& Agung, 2018; Kristanto, Amin, \& Khabibah, 2016). This study has developed the textbook 
so that students rework and synthesize the material to make, construct, produce, devise, and invent their ideas, especially in Complex Numbers material. Students give good feedback about the readable of the textbook by giving a statement that they feel easier to understand the Complex Numbers material using this textbook in comparison with another book as the main source. They gave feedback about the question in the textbook need to be improved such that they can answer it constructively without teacher assistance. However, for further study, it needs more revision to make the students can actively ask the concept given in the textbook directly without teachers' assistance. As an evaluation, students must not only organize and outline concepts and theories, but they evaluate statements by critiquing, checking, experimenting, judging, testing, detecting, and monitoring during the learning process. Students must make their own decision and articulate the reasons for evaluation.

\section{Conclusion}

To develop a better understanding of the impact that textbooks have on learning, a qualitative investigation was carried out in the development of Complex Variables and its Application textbook by using a 4-D model. In defining, the researcher's adequate materials related to the complex number such as the rational number and real number and its properties. In design, the researcher using open questions to stimulate the students to think critically. Some questions using "Why" and "How" words. The notation of the mathematics symbol must be revised using a correct symbol of the mathematics equation. The terms of the equation should be constructed by using a step-by-step question. Students give good feedback about the readable of the textbook by giving a statement that they feel easier to understand the Complex Numbers material using this textbook in comparison with another book as the main source. As an evaluation, students must not only organize and outline concepts and theories, but they evaluate statements by critiquing, checking, experimenting, judging, testing, detecting, and monitoring during the learning process. Students must make judgments about the material and articulate the reasons for evaluation.

\section{Acknowledgment}

The authors wish to express gratitude to Lembaga Penelitian dan Pengabdian Masyarakat Universitas Ahmad Dahlan (LPPM UAD) for Penelitian Hibah Bersaing (PHB) in developing textbook of Complex Analysis and its Application, especially in Complex Number.

\section{Bibliography}

Apriliana, L. P., Handayani, I., \& Awalludin, S. A. (2019). The Effect of a Problem Centered Learning on Student's Mathematical Critical Thinking. JRAMathEdu (Journal of Research and Advances in Mathematics Education), 4(2), 124-133. https://doi.org/10.23917/jramathedu.v4i2.8386

Cahdriyana, R. A., Richardo, R., Fahmi, S., \& Setyawan, F. (2019). Pseudo-thinking process in solving logic problem. Journal of Physics: Conference Series, 1188(No. 1), 012090. https://doi.org/10.1088/1742-6596/1188/1/012090

Carey, S. S. (2011). A beginner's guide to scientific method. Boston, USA: Cengage Learning. Changwong, K., Sukkamart, \& A.Sisan, B. (2018). Critical thinking skill development: Analysis of a new learning management model for Thai high schools. Journal of International Studies, 11(2), 37-48. https://doi.org/10.14254/2071 
Ennis, R. H. (1958). An appraisal of the watson-glaser critical thinking appraisal. Journal of Educational Research. https://doi.org/10.1080/00220671.1958.10882558

Helmstadter, G. (1965). Watson-Glaser Critical Thinking Appraisal. Journal of Educational Measurement, 2(2), 254-256. Retrieved from www.jstor.org/stable/1434446

Himmah, W. I., Nayazik, A., \& Setyawan, F. (2019). Revised Bloom's taxonomy to analyze the final mathematics examination problems in Junior High School. Journal of Physics: Conference Series, 1188(1), 012028. https://doi.org/10.1088/1742$6596 / 1188 / 1 / 012028$

Khabibah, S., Manuharawati, M., \& Agung, L. (2018). Problem Solving Ability: A case study in Postgraduate Mathematics Student. Mathematics, Informatics, Science, and Education International Conference (MISEIC 2018).https://doi.org/10.2991/miseic$\underline{18.2018 .54}$

Krathwohl, D. R. (2002). A revision of Bloom's taxonomy: An overview. Theory into Practice. 41(4), 212-218. https://doi.org/10.1207/s15430421tip4104 2

Kristanto, Y. D., Amin, S. M., \& Khabibah, S. (2016). The Development of Investigative Learning Materials Using Computer Assisted Instruction in the Topic of Reflection for Grade VII. Journal of Research and Advances in Mathematics Education, 1(2), 172-182. https://doi.org/10.23917/jramathedu.v1i2.4828

Krulik, S., \& Rudnick, J. A. (1995). The New Sourcebook for Teaching Reasoning and Problem Solving in Elementary School. A Longwood Professional Book. Boston, USA: Allyn \& Bacon

Lawhon, D. (1976). Instructional development for training teachers of exceptional children: A sourcebook. Journal of School Psychology. https://doi.org/10.1016/00224405(76)90066-2

Panasuk, R. M. (2010). Three Phase Ranking Framework for Assessing Conceptual Understanding in Algebra Using Multiple Representations. Education, 131(2), 235257. Retrieved from https://pdfs.semanticscholar.org/ff5f/ 1a2be947be6957d85e1369a4de313c4965fe.pdf

Rahayunigrum, A., Setyawan, F., \& Khasanah, U. (2018). Profil Pemecahan Masalah Pada Materi Persamaan Linier Satu Variabel Dengan Menggunakan Pendekatan Model Eliciting Activities (MEAs) Dilihat Dari Kemampuan Matematika. AlphaMath: Journal of Mathematics Education, 4(1), 15-22. http://dx.doi.org/10.30595/ime.v4i1.3480

Rezat, S. (2010). The utilization of mathematics textbooks as instruments for learning. Proceedings of CERME, 6, 1260-1269. Retrieved From http://ife.enslyon.fr/publications/edition-electronique/cerme6/wg7-22-rezat.pdf

Schmidt, H. G., Wagener, S. L., Smeets, G. A. C. M., Keemink, L. M., \& van der Molen, H. T. (2015). On the Use and Misuse of Lectures in Higher Education. Health Professions Education, 1(1), 12-18.https://doi.org/10.1016/i.hpe.2015.11.010

Setyawan, F. (2015). Conceptual Understanding Profile of LEOV Junior High School Students Based on Kolb's Learning Style. International Conference on Mathematics, Science, and Education (ICSME), 61-63. Retrieved from http://icmseunnes.com/2015/wp-content/uploads/2016/03/16 ME.pdf

Smith, D. G. (1977). College classroom interactions and critical thinking. Journal of Educational Psychology, 69(2), 180-190. https://doi.org/10.1037/0022$\underline{0663.69 .2 .180}$

Uribe-Enciso, O. L., Enciso, D. S. U., \& Daza, M. D. P. V. (2017). Critical thinking and its importance in education: some reflections. Rastros Rostros, 19(34), 78-88. https://doi.org/10.16925/ra.v19i34.2144

Zapalska, A. M., Nowduri, S., Imbriale, P., \& Wroblewski, B. (2018). A Framework for Critical 
Thinking Skills Development Across Business Curriculum Using the 21 st Century Bloom 's Taxonomy Keywords. Interdisciplinary Education and Psychology, 2(1), 114. https://doi.org/10.31532/InterdiscipEducPsychol.2.2.002 